\title{
Patterns and Determinants of Gap between Fertility Intentions and Fertility Outcomes in \\ Egypt
}

\author{
Mohamed Ali Hussein Aboakrab \\ Lecturer, Department of Statistics, Faculty of Politics and \\ Economics, Beni-Suef University, Egypt
}

\begin{abstract}
:
This paper describes the current fertility behavior and fertility intentions in Egypt. Moreover, the current paper used Logistic regression model to reveal the factors determining gap between fertility intentions and fertility behavior in Egypt. According to data from Egypt Demographic and Health Survey (EDHS) in 2014, the mean ideal number of children is 3.01 and the mean number of children ever born is 2.69. The results indicate that the higher values of mean ideal number of children and mean number of CEB are demonstrated among uneducated women and families who have child mortality. The findings reveal that wealth index, women's age and women's education decrease the gap between fertility intentions and fertility behavior, while child mortality increases the probability of having a gap between fertility intentions and fertility behavior.
\end{abstract}

Keywords: Fertility - Fertility intentions - Fertility behavior Ideal number of children - Gap- Logistic regression model Egypt 


\section{Introduction}

Fertility is among the most important components of population growth and age structure change [UN, 2020]. Investigation of current fertility is essential in monitoring the progress in any country. Additionally, it is necessary to evaluate the fertility desires in a population for predicting future fertility and to determine the potential unmet need for family planning [Ministry of Health and Population 2015]. Fertility has witnessed a major decline in the world for the past few decades. Globally, fertility rate in 1990 compared to 2019 declined from 3.2 to 2.5 live births per woman. Over the same period, total fertility in subSaharan Africa decreased from 6.3 to 4.6 births per woman [UN, 2020]. Moreover, fertility levels declined in Egypt from 4.58 births per woman in 1990 to 3.28 in 2019 [Knoema 2020].

Across 22 European countries, for every 100 births intended, about 60 births on average occur. Most couples have fewer children than they intended to have, resulting in a gap between fertility behavior and fertility intentions (desired family size) (Harknett and Hartnett 2014). Fertility behavior is the actual number of children for women. Fertility intentions is defined as the number of children couples would have if there were no subjective or economic problems involved in regulating fertility (McClelland 1983).

While much has been written on the determinants of actual and desired fertility in the worldwide (Bhuyan 1996; Choudhury et al.1976; Dinc et al. 2007; Ghaffar and Bhuyan 2000; McNamee 2009, Uddin et al 2011) and in Egypt (AbdelHakim 1990; Casterline et al. 2004; Ibrahim 2014), comparatively little is known about the determinants of the gap between actual and desired fertility in the worldwide (Channon and Harper 2019; Forero and Gamboa 2009; Yong and Wei 2019). Therefore, this paper tries to give an overview of the present status of fertility behavior compared to fertility intentions in Egypt. Additionally, the current paper aims to explore if the 
gap between actual and desired fertility varies by characteristics of women in Egypt. Finally, our review of these research studies demonstrated that the determinants of gap between actual and desired fertility have not been examined in Egypt. To fill this gap, this current paper intends to explore the determinants of gap between actual and desired fertility in Egypt.

\section{Data Source}

The current paper used data from 2014 Egypt Demographic and Health Survey (EDHS) which the most recent dataset available in Egypt. This cross-sectional survey was made under authority of El-Zanaty and the Ministry of Health. It consisted of 21,762 ever married women aged $15-49$. Our present study included 20,884 women who mentioned their ideal number of children and number of children ever born. Table (1) presents the definition and measurement of the variables used in our study.

Table (1): Definition and Measurement of the Dependent and Independent Variables

\begin{tabular}{|l|l|l|}
\hline Variable & Definition & Measurement \\
\hline $\begin{array}{l}\text { Gap in } \\
\text { fertility }\end{array}$ & $\begin{array}{l}\text { Binary variable. It is } \\
\text { calculated by finding the } \\
\text { difference between ideal } \\
\text { number of children and } \\
\text { number of children ever } \\
\text { born. If the two numbers } \\
\text { are equal, there is no gap. }\end{array}$ & $\begin{array}{l}\text { fertility intentions and } \\
\text { fertility behavior } \\
\text { fertility intentions and } \\
\text { fertility behavior }\end{array}$ \\
\hline $\begin{array}{l}\text { Place of } \\
\text { residence }\end{array}$ & $\begin{array}{l}\text { Dummy variable shows } \\
\text { the type of place of } \\
\text { residence whether urban } \\
\text { or rural area }\end{array}$ & 0: Urban \\
& $\begin{array}{l}\text { It Rural } \\
\text { Wealth index a proxy variable for }\end{array}$ & 1: Poorest \\
& economic status & 2: Poorer \\
& & 3: Middle \\
& & 5: Richer \\
\hline
\end{tabular}




\begin{tabular}{|c|c|c|}
\hline Women's age & $\begin{array}{l}\text { Age of woman in 5-year } \\
\text { groups. We recode it to } 3 \\
\text { categories. }\end{array}$ & $\begin{array}{l}1: 15-24 \\
2: 25-39 \\
3: 40-49\end{array}$ \\
\hline $\begin{array}{l}\text { Woman's } \\
\text { education }\end{array}$ & $\begin{array}{l}\text { Categorical variable: the } \\
\text { highest level of education } \\
\text { of woman }\end{array}$ & $\begin{array}{l}\text { 0: No education } \\
\text { 1: Incomplete primary } \\
\text { 2: Complete primary } \\
\text { 3: Incomplete } \\
\text { secondary } \\
\text { 4: Complete secondary } \\
\text { 5: Higher }\end{array}$ \\
\hline $\begin{array}{l}\text { Husband's } \\
\text { education }\end{array}$ & $\begin{array}{l}\text { Categorical variable: the } \\
\text { highest level of education } \\
\text { of husband. }\end{array}$ & $\begin{array}{l}\text { 0: No education } \\
\text { 1: Incomplete primary } \\
\text { 2: Complete primary } \\
\text { 3: Incomplete } \\
\text { secondary } \\
\text { 4: Complete secondary } \\
\text { 5: Higher }\end{array}$ \\
\hline Listening & $\begin{array}{l}\text { Dummy variable: } \\
\text { listening to Radio is one } \\
\text { of means to know } \\
\text { exposure to the media for } \\
\text { women }\end{array}$ & $\begin{array}{l}0: \text { No } \\
1: \text { Yes }\end{array}$ \\
\hline Watching & $\begin{array}{l}\text { Dummy variable: } \\
\text { watching Television is } \\
\text { one of means to know } \\
\text { exposure to the media for } \\
\text { women }\end{array}$ & $\begin{array}{l}\text { 0: No } \\
1: \text { Yes }\end{array}$ \\
\hline Reading & $\begin{array}{l}\text { Dummy variable: reading } \\
\text { Newspapers is one of } \\
\text { means to know exposure } \\
\text { to the media for women }\end{array}$ & $\begin{array}{l}0: \text { No } \\
1: \text { Yes }\end{array}$ \\
\hline $\begin{array}{l}\text { Terminated } \\
\text { pregnancy }\end{array}$ & $\begin{array}{l}\text { Dummy variable: Ever } \\
\text { woman had a terminated } \\
\text { pregnancy }\end{array}$ & $\begin{array}{l}0: \text { No } \\
1: \text { Yes }\end{array}$ \\
\hline $\begin{array}{l}\text { Gender } \\
\text { structure of } \\
\text { children }\end{array}$ & $\begin{array}{l}\text { Categorical variable is } \\
\text { calculated by compare } \\
\text { two variables: number of } \\
\text { sons at home and }\end{array}$ & $\begin{array}{l}\text { 0: Girls equal boys } \\
\text { 1: Girls less than boys } \\
\text { 2: Girls more than } \\
\text { boys } \\
\text { 3: Only girls }\end{array}$ \\
\hline
\end{tabular}


Patterns and Determinants of Gap Mohamed Ali Hussein Accepted date 10/1/2021

\begin{tabular}{|l|l|l|}
\hline & $\begin{array}{l}\text { number of daughters at } \\
\text { home }\end{array}$ & $4:$ Only boys \\
\hline $\begin{array}{l}\text { Contraceptive } \\
\text { use }\end{array}$ & $\begin{array}{l}\text { Dummy variable: } \\
\text { whether woman use any } \\
\text { contraceptive method }\end{array}$ & $\begin{array}{l}\text { 0: No } \\
1: \text { Yes }\end{array}$ \\
\hline $\begin{array}{l}\text { Woman's } \\
\text { work }\end{array}$ & $\begin{array}{l}\text { Dummy variable: } \\
\text { whether woman works } \\
\text { for cash or not }\end{array}$ & $\begin{array}{l}\text { 0: No } \\
1: \text { Yes }\end{array}$ \\
\hline $\begin{array}{l}\text { Parents' } \\
\text { desire for } \\
\text { children }\end{array}$ & $\begin{array}{l}\text { Categorical variable } \\
\text { shows the desire of the } \\
\text { husband and her wife for } \\
\text { children }\end{array}$ & $\begin{array}{l}\text { 1: Both want same } \\
\text { more } \\
3: \text { Husband wants } \\
\text { fewer }\end{array}$ \\
\hline $\begin{array}{l}\text { Surviving } \\
\text { child status }\end{array}$ & $\begin{array}{l}\text { Dummy variable: } \\
\text { whether woman has any } \\
\text { child mortality or not. }\end{array}$ & $\begin{array}{l}\text { 0: Not all survived } \\
1: \text { All survived }\end{array}$ \\
\hline
\end{tabular}

\section{Methodology}

This study aims to test the following statistical hypothesis: $\mathrm{H}_{\mathrm{o}}$ : There is not gap between fertility intentions and fertility behavior. $\mathrm{H}_{1}$ : There is a gap between fertility intentions and fertility behavior

This paper measures the gap between fertility intentions and fertility behavior by calculating the difference between ideal number of children and number of children ever born (CEB). The differences are dichotomized into: "no gap between fertility intentions and fertility behavior" and "gap between fertility intentions and fertility behavior". The gap means that ideal number of children does not equal number of children ever born.

Two types of indicators are used in the descriptive statistics. The first is comparing the average ideal number of children and the actual number of births of women with different characteristics. The second is testing the statistical significance 
association of the distribution of the difference between ideal number of children and number of CEB across explanatory variables by using Chi-square test.

Since the dependent variable, gap between fertility intentions and fertility behavior, is measured as a binary outcome variable, the Logistic regression model is used. The determinants potentially affecting on gap between actual and desired fertility that were included in our study were women's age, contraceptive use, place of residence (urban and rural), having a terminated pregnancy, husband's desire for children, wealth index, status of surviving children, region, gender structure of childbearing children, work status and education of wife and husband.

Logistic regression analysis (LRA) expands the techniques of multiple regression analysis to explore circumstances in which the dependent variable is binary (Dayton 1992).

For a binary response variable $\mathrm{Y}$ and a single independent variable $\mathrm{X}$, recall that $\pi(\mathrm{x})$ denotes the "success" probability at value $x$ [ i.e. the probability that the event $Y$ occurs, $P(Y=1)$ ]. The logistic regression model has linear form for the logit of this probability,

$$
\operatorname{Logit}[\pi(x)]=\log \left(\frac{\pi(x)}{1-\pi(x)}\right)=\alpha+\beta x
$$

Using the exponential function $\exp (\alpha+\beta x)=e^{\alpha+\beta x}$, the logistic regression implies the following formula for the probability $\pi(\mathrm{x})$,

$$
\pi(x)=\frac{\exp (\alpha+\beta x)}{1+\exp (\alpha+\beta x)}
$$

In the case of the general logistic regression model with $\mathrm{k}$ predictors, the model for the log odds is: 


$$
\operatorname{Logit}[P(Y=1)]=\alpha+\beta_{1} x_{1}+\beta_{2} x_{2}+\cdots+\beta_{k} x_{k}
$$

The parameter $\beta_{i}$ denotes to the effect of $X_{i}$ on the log odds that $Y=1$, controlling the other $X s$. For example, $\exp \left(\beta_{\mathrm{i}}\right)$ is the multiplicative effect on the odds of a 1-unit increase in $\mathrm{X}_{\mathrm{i}}$, at fixed levels of the other Xs (Agresti 2007).

\section{Results}

Table (2) summarizes the average ideal number of children and the actual number of children ever born (CEB) for women with different characteristics. One can observe that the average ideal number of children is 3.01 and the average number of CEB is 2.69

The descriptive analysis indicates that the higher values of mean ideal number of children (3.58) and mean number of CEB (3.05) are observed among women live in rural areas especially in rural upper Egypt. Moreover, both average ideal number of children and average number of CEB are higher in upper Egypt than lower Egypt.

The findings demonstrate that there is a decrease in both mean ideal number of children and average number of CEB with increase in level of wealth index. Data from Table (2) shows that average ideal number of children and average number of CEB for mothers from the poorest quintile was 3.42 and 3.36 respectively, while these two means for women from the richest quintile decreased to 2.76 and 2.27 respectively. Moreover, one can notice that the mean ideal number of children is greater than the mean number of CEB for all quintiles of wealth index.

The results show that the higher values of average ideal number of children (3.66) and average number of CEB (3.11) are observed among families whose wife's desire for children is more 
than husband's desire. Governmental policies should target wives not husbands to decrease fertility.

As shown in Table (2), there is an increase in both average ideal number of children and mean number of CEB with increase in women's age. Moreover, average ideal number of children (2.82) is higher than average number of CEB (1.16) for younger mothers, while the opposite is observed for older women.

Regarding gender structure of children, Table (2) indicates that the higher values of average number of CEB are observed among families who have girls more than boys. On the other hand, mean number of CEB is greater among mothers who use contraceptive methods (3.07) than those who do not use (2.12).

The findings indicate that the mean ideal number of children and average number of CEB are higher among families who have child mortality than those who do not have. Data from Table (2) shows that average ideal number of children and average number of CEB for families who have child mortality was 3.53 and 4.72 respectively, while these two means for families who do not have child mortality decreased to 2.96 and 2.48 respectively.

Regarding women's education, one can observe that the average ideal number of children of women with illiteracy and incomplete primary is less than the mean number of CEB; meanwhile, the mean ideal number of children starts to be greater than mean number of CEB from women with complete primary.

Table (2): Average ideal number of children and average number of children ever born with different characteristics for women 


\begin{tabular}{|c|c|c|}
\hline characteristics & $\begin{array}{l}\text { Average } \\
\text { ideal } \\
\text { number of } \\
\text { children }\end{array}$ & $\begin{array}{l}\text { Average } \\
\text { number of } \\
\text { children }\end{array}$ \\
\hline $\begin{array}{ll}\text { Women's age } & 15-24 \\
& 25-39 \\
& 40-49\end{array}$ & $\begin{array}{l}2.82 \\
2.96 \\
3.29\end{array}$ & $\begin{array}{l}1.16 \\
2.70 \\
3.84\end{array}$ \\
\hline $\begin{array}{l}\text { Place of residence } \\
\text { Rural } \\
\text { Urban }\end{array}$ & $\begin{array}{l}3.09 \\
2.87\end{array}$ & $\begin{array}{l}2.76 \\
2.51\end{array}$ \\
\hline $\begin{array}{l}\text { Region } \\
\text { Urban governorates } \\
\text { Urban Lower Egypt } \\
\text { Rural Lower Egypt } \\
\text { Urban Upper Egypt } \\
\text { Rural Upper Egypt } \\
\text { Frontier governorates }\end{array}$ & $\begin{array}{l}2.75 \\
2.73 \\
2.75 \\
3.12 \\
3.58 \\
3.46\end{array}$ & $\begin{array}{l}2.34 \\
2.46 \\
2.57 \\
2.75 \\
3.05 \\
2.64\end{array}$ \\
\hline $\begin{array}{l}\text { Education of women } \\
\text { No education } \\
\text { Incomplete primary } \\
\text { Complete primary } \\
\text { Incomplete secondary } \\
\text { Complete secondary } \\
\text { Higher }\end{array}$ & $\begin{array}{c}3.34 \\
3.23 \\
3 \\
3 \\
2.86 \\
2.84\end{array}$ & $\begin{array}{l}3.52 \\
3.32 \\
2.83 \\
2.41 \\
2.40 \\
2.05\end{array}$ \\
\hline $\begin{array}{rr}\text { Woman's work } & \text { No } \\
& \text { Yes }\end{array}$ & $\begin{array}{c}3.03 \\
2.9\end{array}$ & $\begin{array}{l}2.67 \\
2.72\end{array}$ \\
\hline $\begin{array}{rr}\text { Terminated pregnancy } & \text { No } \\
& \text { Yes }\end{array}$ & $\begin{array}{l}2.97 \\
3.17\end{array}$ & $\begin{array}{l}2.57 \\
3.07\end{array}$ \\
\hline $\begin{array}{ll}\text { Contraceptive use } & \text { No } \\
\text { Yes }\end{array}$ & $\begin{array}{l}3.10 \\
2.95\end{array}$ & $\begin{array}{l}2.12 \\
3.07\end{array}$ \\
\hline $\begin{array}{rr}\text { Wealth index } & \text { Poorest } \\
& \text { Poorer } \\
\text { Middle } & \text { Richer } \\
\text { Richest }\end{array}$ & $\begin{array}{l}3.42 \\
3.21 \\
2.92 \\
2.83 \\
2.76\end{array}$ & $\begin{array}{l}3.36 \\
2.98 \\
2.51 \\
2.39 \\
2.27\end{array}$ \\
\hline
\end{tabular}


Patterns and Determinants of Gap Mohamed Ali Hussein $\quad$ Accepted date 10/1/2021

\begin{tabular}{|c|c|c|}
\hline $\begin{array}{lr}\text { Listening } & \text { No } \\
& \text { Yes }\end{array}$ & $\begin{array}{l}3.05 \\
2.89\end{array}$ & $\begin{array}{l}2.71 \\
2.56\end{array}$ \\
\hline Watching & $\begin{array}{l}3.21 \\
3.01\end{array}$ & $\begin{array}{l}2.89 \\
2.67\end{array}$ \\
\hline $\begin{array}{ll}\text { Reading } & \text { No } \\
& \text { Yes }\end{array}$ & $\begin{array}{l}3.04 \\
2.85\end{array}$ & $\begin{array}{l}2.71 \\
2.44\end{array}$ \\
\hline $\begin{array}{l}\text { Husband's education } \\
\text { No education } \\
\text { Incomplete primary } \\
\text { Complete primary } \\
\text { Incomplete secondary } \\
\text { Complete secondary } \\
\text { Higher }\end{array}$ & $\begin{array}{c}3.27 \\
3.13 \\
3 \\
2.96 \\
2.95 \\
2.91\end{array}$ & $\begin{array}{l}3.37 \\
3.20 \\
2.85 \\
2.65 \\
2.44 \\
2.29\end{array}$ \\
\hline $\begin{array}{l}\text { Parents' desire for children } \\
\text { Both want same } \\
\text { Husband wants more } \\
\text { Husband wants fewer }\end{array}$ & $\begin{array}{l}2.94 \\
3.05 \\
3.66 \\
\end{array}$ & $\begin{array}{l}2.67 \\
2.67 \\
3.11 \\
\end{array}$ \\
\hline $\begin{array}{l}\text { Gender structure of children } \\
\text { Girls equal boys } \\
\text { Girls less than boys } \\
\text { Girls more than boys } \\
\text { Only girls } \\
\text { Only boys }\end{array}$ & $\begin{array}{l}2.89 \\
3.37 \\
3.31 \\
2.83 \\
2.85\end{array}$ & $\begin{array}{l}1.98 \\
3.89 \\
3.99 \\
2.05 \\
2.28 \\
\end{array}$ \\
\hline $\begin{array}{l}\text { Surviving child status } \\
\text { Not all survived } \\
\text { All survived }\end{array}$ & $\begin{array}{l}3.53 \\
2.96\end{array}$ & $\begin{array}{l}4.72 \\
2.48\end{array}$ \\
\hline Mean & 3.01 & 2.69 \\
\hline
\end{tabular}

Table (3) introduced percentage distribution of gap between actual and desired fertility among women with different characteristics with Chi-square test. The results show that wealth index significantly decreases the gap in fertility (gap between fertility intentions and fertility behavior). About 73 percent of mothers who are in the poorest quintile had a gap in fertility, while this percentage declined to about 61 percent among mothers who are in the richest quintile. 
The results demonstrate that there is a significant association between having a gap in fertility and women's age. About 86 percent among women aged 15-24 had a gap in fertility, while this percentage declined to 64 percent among mothers aged 40-49.

With respect to gender structure of children, Table (3) shows that about 66 percent of families who have the same number of boys and girls had a gap in fertility, while this percentage expanded to about 77 percent among families who have only girls. On the other hand, as indicated in Table (3), about 65 percent of parents who have the same desire for children had a gap in fertility, while this percentage expanded to about 79 percent among families whose husband's desire for children is less than the wife.

Regarding education, there is a significant association between education of women and having a gap in fertility. Table (3) shows that about 70 percent of mothers who have never gone school had a gap in fertility, while this percentage decreased to about 67 percent among mothers with university education or higher. On the other hand, women's work significantly decreases the gap in fertility. The findings demonstrate that 69 percent of mothers who do not work had a gap in fertility, while this percentage declined to 65 percent among mothers who work.

With respect to status of surviving children, Table (3) demonstrates that about 81 percent among women who have child mortality had a gap in fertility, while this percentage declined to 67 percent among mothers who do not have child mortality.

One can observe that exposure to the media significantly decreases gap in fertility. The findings demonstrate that 76 percent of mothers who do not watch Television had a gap in fertility, while this percentage declined to 68 percent among mothers who watch Television. Moreover, as can be seen from 
Table (3), about 61 percent among women who use contraceptive method had a gap in fertility, while this percentage expanded to about 78 percent among mothers who do not use contraceptive method.

According to Table (3), a significant association between place of residence and having a gap in fertility is observed. About 63 percent of women live in urban areas had a gap in fertility compared about 71 percent among women live in rural areas. At the same time, there is a significant association between region and having a gap in fertility. The results show that the highest percentage of having a gap in fertility is observed among families who live in rural upper Egypt (76 percent), while the lowest percentage is in urban governorate (61 percent).

Table 3: Percentage distribution of gap between fertility intentions and fertility behavior among women with different characteristics

\begin{tabular}{|c|c|c|c|}
\hline Characteristics & $\begin{array}{l}\text { No gap } \\
\text { in } \\
\text { fertility }\end{array}$ & $\begin{array}{l}\text { Gap in } \\
\text { fertility }\end{array}$ & $\mathrm{N}$ \\
\hline $\begin{array}{ll}\text { Women's age } & 15-24 \\
& 25-39 \\
& 40-49\end{array}$ & $\begin{array}{l}13.9 \\
35.6 \\
35.8\end{array}$ & $\begin{array}{l}86.1 \\
64.4 \\
64.2\end{array}$ & $\begin{array}{c}3722 \\
11926 \\
5235\end{array}$ \\
\hline $\begin{array}{ll}\text { Place of residence* } & \begin{array}{l}\text { Rural } \\
\text { Urban }\end{array}\end{array}$ & $\begin{array}{l}29.1 \\
36.8\end{array}$ & $\begin{array}{l}70.9 \\
63.2\end{array}$ & $\begin{array}{c}13565 \\
7319\end{array}$ \\
\hline $\begin{array}{l}\text { Region* } \\
\text { Urban governorates } \\
\text { Urban Lower Egypt } \\
\text { Rural Lower Egypt } \\
\text { Urban Upper Egypt } \\
\text { Rural Upper Egypt } \\
\text { Frontier governorates }\end{array}$ & $\begin{array}{c}39.5 \\
37 \\
32.7 \\
34 \\
23.6 \\
27.3\end{array}$ & $\begin{array}{c}60.5 \\
63 \\
67.3 \\
66 \\
76.4 \\
72.7 \\
\end{array}$ & $\begin{array}{c}2655 \\
2235 \\
8147 \\
2333 \\
5348 \\
165 \\
\end{array}$ \\
\hline $\begin{array}{l}\text { Woman's education* } \\
\text { No education } \\
\text { Incomplete primary }\end{array}$ & $\begin{array}{l}30.3 \\
31.8\end{array}$ & $\begin{array}{l}69.7 \\
68.2\end{array}$ & $\begin{array}{l}4866 \\
1251\end{array}$ \\
\hline
\end{tabular}

Scientific Journal for Economic\& Commerce 
Patterns and Determinants of Gap Mohamed Ali Hussein Accepted date 10/1/2021

\begin{tabular}{|c|c|c|c|}
\hline \multirow{4}{*}{$\begin{array}{l}\text { Complete primary } \\
\text { Incomplete secondary } \\
\text { Complete secondary } \\
\text { Higher }\end{array}$} & 33.6 & 66.4 & 866 \\
\hline & 28.4 & 71.6 & 2798 \\
\hline & 33.1 & 66.9 & 8167 \\
\hline & 33.3 & 66.7 & 2936 \\
\hline \multirow[t]{2}{*}{ Woman's work* } & 31.2 & 68.8 & 17892 \\
\hline & 35.1 & 64.9 & 2992 \\
\hline \multirow{2}{*}{$\begin{array}{l}\text { Terminated pregnancy* } \\
\text { No }\end{array}$} & 32.1 & 67.9 & 16589 \\
\hline & 30.7 & 69.3 & 4295 \\
\hline \multicolumn{4}{|l|}{ Yes } \\
\hline \multirow{2}{*}{$\begin{array}{l}\text { Contraceptive use* } \\
\text { No }\end{array}$} & 22.4 & 77.6 & 9352 \\
\hline & 39.4 & 60.6 & 11531 \\
\hline \multicolumn{4}{|l|}{ Yes } \\
\hline \multirow[t]{5}{*}{ Wealth index* } & 27.3 & 72.7 & 3616 \\
\hline & 30 & 70 & 4115 \\
\hline & 30.4 & 69.6 & 4689 \\
\hline & 31.9 & 68.1 & 4397 \\
\hline & 39.1 & 60.9 & 4066 \\
\hline \multirow{2}{*}{ Listening** } & 31.4 & 68.6 & 16259 \\
\hline & 33.1 & 66.9 & 4624 \\
\hline \multirow[t]{2}{*}{ Watching* } & 23.8 & 76.2 & 311 \\
\hline & 31.9 & 68.1 & 20572 \\
\hline \multirow[t]{2}{*}{ Reading* } & 31.4 & 68.6 & 17883 \\
\hline & 34.3 & 65.7 & 3000 \\
\hline Education of Husband* & & & \\
\hline No education & 33.2 & 66.8 & 3517 \\
\hline Incomplete primary & 31 & 69 & 1771 \\
\hline Complete primary & 34.5 & 65.5 & 1187 \\
\hline Incomplete secondary & 30 & 70 & 2480 \\
\hline Complete secondary & 31 & 69 & 8516 \\
\hline Higher & 33.1 & 66.9 & 3410 \\
\hline \multirow{2}{*}{$\begin{array}{l}\text { Parents' desire for children* } \\
\text { Both want same }\end{array}$} & & & \\
\hline & 35.3 & 64.7 & 13043 \\
\hline Husband wants more & 25.6 & 74.4 & 4599 \\
\hline
\end{tabular}




\begin{tabular}{|l|c|c|c|}
\hline Husband wants fewer & 21.4 & 78.6 & 1012 \\
\hline Gender structure of children* & & & \\
Girls equal boys & 33.6 & 66.4 & 6080 \\
Girls less than boys & 36.1 & 63.9 & 3457 \\
Girls more than boys & 31.9 & 68.1 & 2997 \\
Only girls & 23.5 & 76.5 & 3266 \\
Only boys & 32 & 68 & 5083 \\
\hline Surviving child status* & & & \\
Not all survived & 19.2 & 80.8 & 1889 \\
All survived & 33 & 67 & 18994 \\
\hline
\end{tabular}

$*$ Sig. $<1 \% \quad * *$ Sig. $<5 \%$

Table (4) presents the results of goodness of fit of the logistic regression model to explore the determinants of gap between actual and desired fertility. One can observe that the final model can predict correctly about 70 percent of the cases. Additionally, chi-square is highly significant, so our model is significantly better.

Table (4): Goodness of fit for logistic regression for exploring the determinants of gap between fertility intentions and fertility behavior

\begin{tabular}{|c|c|c|c|c|}
\hline \multirow{2}{*}{\multicolumn{2}{|c|}{ Classification Table }} & \multicolumn{2}{|c|}{ Predicted } & \multirow{2}{*}{$\begin{array}{c}\text { Percentage } \\
\text { Correct }\end{array}$} \\
\hline & & No gap & Gap & \\
\hline \multirow[t]{2}{*}{ Observed } & No gap & 1381 & 4812 & 22.3 \\
\hline & Gap & 992 & 12223 & 92.5 \\
\hline \multicolumn{2}{|c|}{ Overall Percentage } & & & 70.1 \\
\hline \multicolumn{2}{|c|}{ Chi-Square } & \multicolumn{3}{|c|}{1973.549} \\
\hline \multicolumn{2}{|c|}{ Sig. } & \multicolumn{3}{|c|}{0.000} \\
\hline \multicolumn{2}{|c|}{ Cox \& Snell R Square } & \multicolumn{3}{|c|}{0.097} \\
\hline \multicolumn{2}{|c|}{ Nagelkerke R Square } & \multicolumn{3}{|c|}{0.135} \\
\hline
\end{tabular}


Table (5) presents the significant variables of the logistic regression model to explore the determinants of gap between actual and desired fertility. The results of Table (5) demonstrate that women's education significantly decreases the likelihood of having a gap in fertility (gap between fertility intentions and fertility behavior). As indicated in Table (5), mothers who have achieved secondary are less likely to have a gap in fertility compared with mothers who have never attended school by about 17 percent $(0.827-1=-0.173)$.

The analysis indicates that child mortality significantly increases the probability of having a gap in fertility. Table (5) shows that families who have child mortality are two times more likely to have a gap in fertility than those who do not have child mortality.

It is possible to observe that women from urban upper Egypt are more likely to have a gap in fertility than women from urban governorates by about 16 percent $(1.163-1=0.163)$. Moreover, women from frontier governorates are more likely to have a gap in fertility than women from urban governorates by about 55 percent $(1.546-1=0.546)$.

The findings reveal that the higher level of wealth index, the less likely the woman has a gap in fertility. According to Table (5), women from the poorer quintile are less likely to have a gap in fertility than women from the poorest quintile by about 9 percent. Moreover, women from the richest quintile are less likely to have a gap in fertility than women from the poorest quintile by about 17 percent.

One can observe that age of mother has a negative impact on the probability of having a gap in fertility. Data from Table (5) shows that women aged 25-39 and 40-49 years are less likely to have a gap in fertility than women aged 15-24 years by about 68 
percent and 70 percent, respectively. Moreover, another predictor for having a gap in fertility was contraceptive use. Table (5) reveals that women who use contraceptive method are less likely to have a gap in fertility than women who do not use contraceptive method by about 55 percent.

As shown in Table (5), families whose husband's desire for children is less than the wife are two times more likely to have a gap in fertility than parents who have the same desire for children. Moreover, families whose husband's desire for children is more than the wife are more likely to have a gap in fertility than parents who have the same desire for children by about 41 percent.

Regarding gender structure of children, families who have only girls are more likely to have a gap in fertility than families who have same number of boys and girls by about 79 percent. Moreover, families who have only boys are more likely to have a gap in fertility than families who have same number of boys and girls by about 24 percent. Additionally, families who have girls less than boys are more likely to have a gap in fertility than families who have same number of boys and girls by about 30 percent. Also, families who have girls more than boys are more likely to have a gap in fertility than families who have same number of boys and girls by about 56 percent. 
Table (5): Results of logistic regression for exploring the determinants of gap between fertility intentions and fertility behavior

\begin{tabular}{|l|c|c|c|}
\hline characteristics & $\begin{array}{c}\text { Odds } \\
\text { Ratio } \\
\text { (OR) }\end{array}$ & S.E. & Wald \\
\hline \multicolumn{1}{|c|}{ 15-24-39 (ref.) } & & & \\
\hline Age of mother & $0.322^{*}$ & 0.056 & 416.50 \\
& $0.300^{*}$ & 0.064 & 353.70 \\
\hline Region & & & \\
Urban governorates(ref.) & 1.033 & 0.065 & 0.254 \\
Urban Lower Egypt & 1.180 & 0.360 & 0.211 \\
Rural Lower Egypt & $1.163^{* *}$ & 0.066 & 5.28 \\
Urban Upper Egypt & 1.536 & 0.361 & 1.41 \\
Rural Upper Egypt & $1.546^{* * *}$ & 0.240 & 3.30 \\
Frontier governorates & & & \\
\hline Woman's education & & & \\
No education (ref.) & $0.853^{* *}$ & 0.078 & 4.13 \\
Incomplete primary & 0.878 & 0.089 & 2.12 \\
Complete primary & $0.829 *$ & 0.062 & 9.09 \\
Incomplete secondary & $0.827 *$ & 0.054 & 12.35 \\
Complete secondary & 0.911 & 0.079 & 1.38 \\
Higher & & & \\
\hline Contraceptive use No(ref.) & $0.454 *$ & 0.036 & 487.87 \\
\hline Yes & & & \\
\hline Wealth index Poorest (ref.) & & & \\
Poorer & $0.907 * * *$ & 0.055 & 3.09 \\
Middle & 0.975 & 0.056 & 0.203 \\
Richer & 1.009 & 0.067 & 0.018 \\
Richest & $0.834^{* *}$ & 0.085 & 4.52 \\
\hline Education of Husband & & & \\
No education(ref.) & $1.234 *$ & 0.070 & 8.98 \\
Incomplete primary & $1.211^{*}$ & 0.080 & 1.09 \\
Complete primary & 0.056 & 11.88 \\
Incomplete secondary & 11.66 \\
\hline
\end{tabular}


Patterns and Determinants of Gap Mohamed Ali Hussein Accepted date 10/1/2021

\begin{tabular}{|l|c|c|c|}
\hline Complete secondary & $1.259^{*}$ & 0.073 & 9.81 \\
\hline Higher & & & \\
Parents' desire for children & & & \\
Both want same(ref.) & & & \\
Husband wants more & $1.405^{*}$ & 0.041 & 70.48 \\
\hline Gender structure of children & & & \\
Girls equal boys(ref.) & & & \\
Girls less than boys & $1.297 *$ & 0.050 & 27.05 \\
Girls more than boys & $1.562^{*}$ & 0.053 & 72.05 \\
Only girls & $1.787 *$ & 0.054 & 113.50 \\
Only boys & $1.244^{*}$ & 0.045 & 23.76 \\
\hline Surviving child status & & & \\
All survived (ref.) & & & \\
Not all survived & $2.200^{*}$ & 0.066 & 143.24 \\
\hline
\end{tabular}

*Sig. $<1 \% \quad * *$ Sig. $<5 \% \quad * * *$ Sig. $<10 \%$

\section{Discussion}

One can observe that the average desired family size in Egypt is reasonable. The findings demonstrate that the average ideal number of children in Egypt is 3.01 as compared to 5 in subSaharan Africa (Channon and Harper 2019), 1.82 in China (Yong and Wei 2019) and 2.9 in other low and middle income countries (Channon and Harper 2019).

The results indicate that the higher values of average ideal number of children and average number of CEB are demonstrated among families who have child mortality. Moreover, child mortality increases the probability of having a gap in fertility. The findings of other studies also reflect that child mortality had a positive impact on level of fertility (Bhuyan 1996; Choudhury et al.1976. Ghaffar and Bhuyan 2000; Uddin et al 2011).

Consistent with previous findings (Yong and Wei 2019), actual number of births is higher than the desired number of children among women aged 40-49 who basically completed 
childbirth. The findings show that age of mother has a negative impact on the probability of having a gap in fertility where older mothers are less likely to have a gap in fertility than younger mothers.

The analytical results reveal that with the increase in level of wealth index, decline in average of ideal number of children and CEB are demonstrated. The findings indicate that the lower values of average ideal number of children and average number of CEB are observed among women from the richest quintile. Moreover, wealth index decreases gap in fertility. This is also demonstrated in many studies (Bhuyan 1996; Uddin et al 2011).

It can be concluded that there is a negative relationship between education of women and having a gap in fertility where women's education decreases the likelihood of having a gap in fertility. Moreover, the high ideal number of children is noticed among highly educated women. This is also found in many countries worldwide (Beaujouan and Berghammer 2019; Channon and Harper 2019).

It can be noticed that mothers who utilize contraceptive methods are less likely to have a gap in fertility than women who do not use contraceptive methods. Moreover, mean number of CEB is higher among women who use contraceptive methods than those who do not use. This result is supported by a study in Bangladesh. This finding may be because of uneducated couples may utilize contraceptive methods without care which may lead them to unwanted pregnancy (Uddin et al 2011).

Consistent with previous findings (Yong and Wei 2019), gender structure of children is one of the predictor variables determining the gap between actual and desired fertility. The results indicate that families who have different number of boys and girls are more likely to have a gap in fertility than families who have same number of boys and girls. Moreover, families who 
have only boys or girls are more likely to have a gap in fertility than families who have same number of boys and girls.

\section{Concluding remarks}

This paper tried to describe the current fertility behavior and fertility intentions in Egypt using data from EDHS in 2014. Additionally, Logistic regression model is utilized to explore the determinants of gap between fertility intentions and fertility behavior in Egypt. It can be concluded that there is no recent research on this variable in Egypt and this is the main contribution of our study.

The findings reveal that women's education decreases the probability of having a gap between actual and desired fertility. Therefore, governmental strategy should concentrate on those out of the formal educational system by giving more information about consequences of reproductive behavior.

Our paper did not be care whether fertility behavior is more or less than fertility intentions, but it aims to know whether there is a gap or not. Therefore, future research may explore determinants of underachieving, equaling, and overachieving fertility intentions in Egypt.

\section{References}

[1] Abdel-Hakim, M. (1990). A Statistical Analysis of Determinants of Actual and Desired Family Size in Rural and Urban Egypt. Unpublished M.Sc. thesis, Faculty of Economic and Political Science, Cairo university, Egypt.

[2] Agresti, A. (2007). An Introduction to Categorical Data Analysis. Second Edition, JohnWiley \& Sons, Inc., Hoboken, New Jersey

[3] Beaujouan E and Berghammer C (2019). The Gap Between Lifetime Fertility Intentions and Completed Fertility in Europe and the United States: A Cohort Approach. Population Research and Policy Review, https://doi.org/10.1007/s11113-019-09516-3 
[4] Bhuyan KC (1996). Fertility Differentials According to SocioEconomic Status and Family Planning Adoption in Rural Bangladesh. Indian Journal of Statistics, 58 (2), 302-322.

[5] Casterline J, El-Zanaty F and El-Zeini L (2004). Unmet need and unintended fertility: longitudinal evidence from Upper Egypt. International Perspectives on Sexual and Reproductive Health, 29 (4), 158-66.

[6] Channon MD and Harper S (2019). Educational differentials in the realisation of fertility intentions: Is sub-Saharan Africa different. PLoS ONE 14(7): e0219736. https://doi.org/10.1371/journal.pone.0219736

[7] Choudhury et al. (1976). The effect of child mortality experience on subsequent fertility. Population Studies, 30, 249-261.

[8] Dayton, C. M. (1992). Logistic Regression Analysis. Department of Measurement Statistics and Evaluation, University of Maryland. Available from:

https://www.researchgate.net/publication/268416984 Logistic Regres $\underline{\text { sion_Analysis }}$

[9] Dinc G, Eser E, Cihan UA, Ay S, Pala T, Ergor G, Ozcan C(2007). Fertility preferences, contraceptive behaviors and unmet needs: a gap between urban and suburban parts of a city. The European Journal of Contraception and Reproductive Health Care March, 12(1):86-94.

[10] Forero N, Gamboa LF (2009). Family Size in Colombia: Guessing or Planning? Intended vs. Actual Family Size in Colombia. Desarrollo y Sociedad 64:85-118.

[11] Ghaffar FM and Bhuyan, KC (2000). Regional Variations in Child Mortality in North-Eastern Libya. The Journal of Family Welfare, 46(1).

[12] Harknett K and Hartnett CS (2014). The gap between births intended and births achieved in 22 European Countries, 2004-07. Population Studies, 68(3), 265-282. 
[13] Ibrahim MHA (2014). Determinants of Wanted Fertility in Egypt. Unpublished M.Sc. thesis, Faculty of commerce, Sadat City university, Egypt.

[14] Knoema (2020). World data alts [Cited 2020 October 11]. Available from:

https://knoema.com/atlas/Egypt/topics/Demographics/Fertility/Fertilit y-rate

[15] McClelland, G. (1983). Family-size desires and measures of demand. Bulatao, R A, Lee, R. Determinants of fertility in developing countries, Academic Press, New York.

[16] McNamee CB (2009). Wanted and Unwanted Fertility in Bolivia: Does Ethnicity Matter?. International Perspectives on Sexual and Reproductive Health, 35(4):166-175.

[17] Ministry of Health and Population [Egypt], El-Zanaty and Associates [Egypt], and ICF International. (2015). Egypt Demographic and Health Survey 2014. Cairo, Egypt and Rockville, Maryland, USA:Ministry of Health and Population and ICF International.

[18] United Nations Department of Economic and Social Affairs, Population Division (2020). World Fertility and Family Planning 2020: Highlights. New York

[19] Yong J and Wei C (2019). Gaps between Fertility Intensions and Fertility Outcomes in China: Patterns and Determinants. Center for Population and Development Studies, Renmin University, Beijing, China. 